\title{
骨セメントを用いた下顎区域切除術の際の下顎の簡便な復位法
}

\author{
蜂矢裕司・白水敬昌・成田幸憲 \\ 池 昌男*·宮地 斉*·河合俊彦*
}

\section{A simplified method for mandibular repositioning using acrylic bone cement during segmental mandibulectomy}

\author{
Hiroshi HachiYa $\cdot$ Takamasa ShIROzU $\cdot$ Takanori NARita \\ Masao IKE* ${ }^{*}$ Hitoshi MiYACHI ${ }^{*}$ Tosihiko KAWAI*
}

\begin{abstract}
Loss of mandibular continuity due to segmental mandibulectomy leads to esthetic and functional problems. Restoration of mandibular continuity after segmental mandibulectomy is one of the chalenges of reconstructive surgery.

In this paper, a simple technique is described which utilizes acrylic bone cement for a template of the mandible.

Before mandibular resection, mandibular continuity is restored with soft acrylic bone cement contained in a flexible tube. The tube is attached to residual sites with small monocortical screws. The tube is held until the cement solidifies. When the bone cement has hardened, the tube can be removed.

After mandibular resection, the tube is replaced to realign the mandibular segment and correctly restore the patient's occlusion and facial esthetics.
\end{abstract}

Key words: bone cement (骨セメント), segmental mandibulectomy (下顎区域切除術), mandibular replacement (下䫟骨の復位), mandibular reconstruction（下頢再建術）

はじめに

下顎区域切除の際に, 残存下顎骨を容易かつ正確に 復位させる方法を考案したので, その術式を報告する.

\section{1. 使用材料}

\section{材料 と術式}

骨セメント (ハウメデカ社製サージカル・シンプレッ クス), ミニプレート用骨ネジ, 内径 $8 \mathrm{~mm}$ 程度の柔軟 なチューブ.

\footnotetext{
臨港病院歯科口腔外科

（主任 : 成田幸憲部長）

*愛知学院大学歯学部口腔外科学第 2 講座

(主任 : 河合 幹教授)

Division of Dentistry and Oral Surgery, Rinkou

Hospital (Chief: Takanori Narita)

*Second Department of Oral and Maxillo facial Surgery, School of Dentistry Aichi-Gakuin University (Chief: Prof. Tsuyoshi Kawai)

受付日: 平成 8 年 2 月 15 日
}

\section{2. 術式}

1 ) 顎位保持装置 (後述) を固定するためのネジ止 め固定装置を, 即時重合レジンを用いて, 適当な形態 にあらかじめ複数作製しておく.

2 ) 全術野が明視できる状態下で，区域切除前に, 前記の固定装置を切離部外側にネジ止めする. その際, 骨との空隙に骨セメントを充填すると, ネジ止め時に 装置が破損するのを防止できる（写真 1 ).

3 ) 固定装置間にチューブを試適して, 必要な長さ に切断しチューブ内に骨セメントを注入する.チュー ブ断端における骨セメントを固定装置に接触させて硬 化するまで保持すると，顎位保持装置が完成する．才 トガイ部や下顎角部など突出部を含む再建では，その 位置をチューブに印記しておくと, 再建術の際に位置 決定をする目安となる (写真 2 ).

4 ) 架橋した顎位保持装置を一時除去し,下顎骨の 区域切除を実施する。

5 ) 顎位保持装置の再固定により顎の復位を行い, 


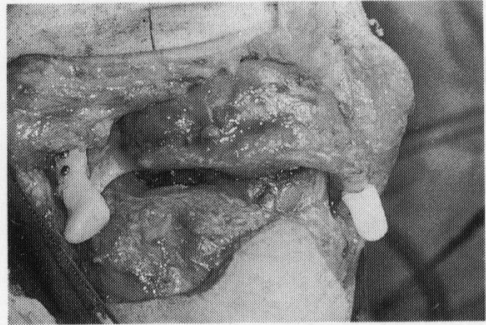

写真 1 区域切除前にネジ止めされた固定装置

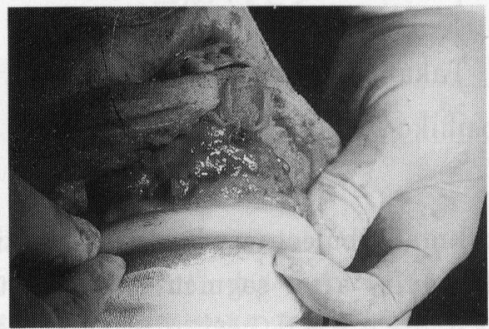

写真 2 チューブに骨セメントを注入し固定装 置と接触させ数分間保持する

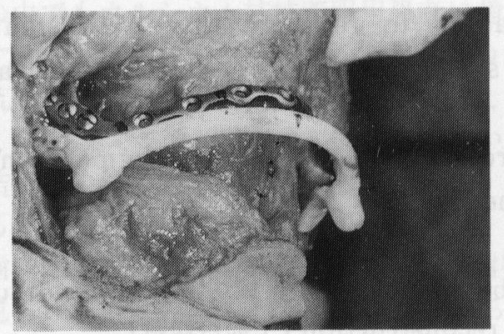

写真 3 顎位保持装置を再固定し残存顎を復位 固定させた後, プレートを屈曲させネジ止め固 定した状態

その顎位でプレートの屈曲, 適合, ネジ止めを行う (写真 3 ).

6 ）頡位保持装置を除去して下顎再建を終了する (写真 4 ).

症例により骨移植を併用する。

以下に代表的症例を供覧する.

症例

患 者: 66 歳男性.

初診: 1992 年 12 月日日.

主 訴: 下顎歯肉腫脹.

家族歴 : 特記事項なし.

既往歴 : 特記事項なし.

現病歴 : 1992 年 10 月頃より右下頢歯肉の腫脹, 11 月末より右下口唇知覚麻瘏を自覚し来院した。

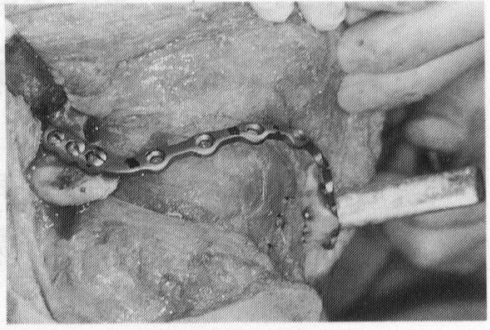

写真 4 顎位保持装置を除去し, プレートで顎 位が保持された状態

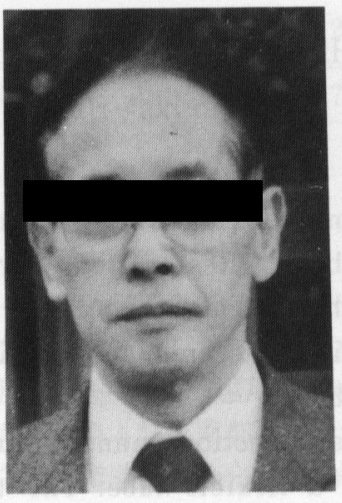

$\mathrm{a}$ : 術前の正貌

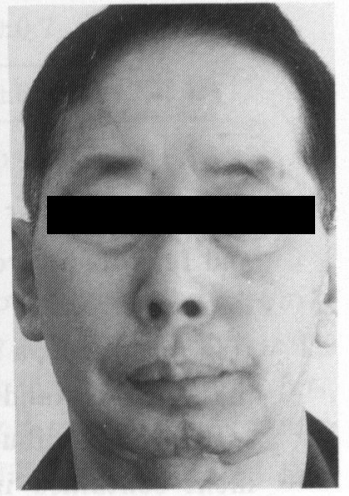

$\mathrm{b}$ : 術後 3 年目の正貌
写真 5

a

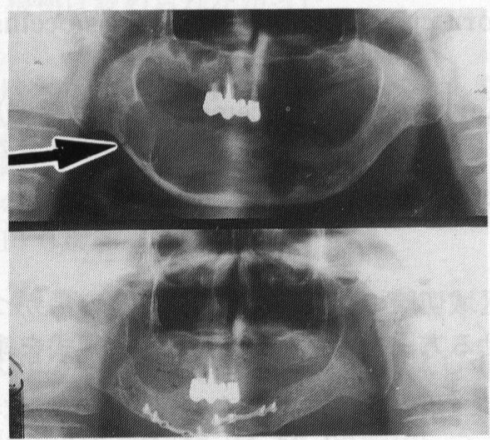

写真 6

$\mathrm{a}$ : 術前のパノラマ X 線写真 (矢印は病的 骨折部を示す）

$\mathrm{b}$ : 術後 3 年目のパノラマ $\mathrm{X}$ 線写真

現 症 : 顔貌は右下顎部の軽度びまん性腫脹を観る のみで著変はない(写真 $5 \mathrm{a}$ ). 口腔内は右下顎歯肉が 鶏卵大に膨隆していたＸ線写真では, 腫瘍は右下顎 角部から左オトガイ孔付近に存在し, 右下顎角部で病 的骨折を生じていた (写真 6 a).

臨床診断：下顎骨良性腫瘍.

病理組織学的所見: エナメル上皮腫. 
処置および経過：1993 年 2 月—に右下顎角部から 左オトガイ孔部の間の下顎区域切除を行った。 区域切 除の後, 前述の方法によりチタンプレートによる下顎 再建を行い, 併せて遊離腸骨移植を行った。

術後 1 年目にプレートを除去し，歯槽堤形成を目的 に再度の遊離腸骨移植を行った。術後 3 年の現在, 総 義㐘を装着し常食を摂取し, 顔面形態もほほ満足を得 られている (写真 5 b) . X 線写真でも, 移植骨周囲に 新生骨の形成が観られ，下顎骨高径が充分に得られて いることが観察できる(写真 6 b).

上記の症例以外にも, 有歯顎の 3 症例に同様の復位 法を応用し, 最長で 1 年 9 か月間, 経過観察中である が，いずれの症例も良好な結果を得ている。

\section{考察}

1 ) 残存下顎骨の復位, 固定法について

残存下顎骨の簡便な復位法としては, 区域切除術前 の切断部間の距離計測 ${ }^{1)}$, 顎間固定 ${ }^{2)}$ などが挙げら れる.

これらの方法は, 残存下顎が強固に固定されていな い状態下で, 再建顎の位置決定をする欠点を有する. また, 復位の正確性の梷でも, 残存下顎骨は区域切除 後には咀嚼筋に牽引されるので, 距離計測のみでは三 次元的な位置の復位に関しては不正確となるし，顎間 固定を併用しても，残存下顎骨の煩舌側的な傾斜を防 止できない。

残存下顎骨を復位, 固定した後に再建術を行う方法 としては，区域切除前にプレートを仮固定し，切除後 に再固定して下顎骨を復位させる術式 3,4$)$ が挙げら れる.

この方法は, 区域切除前の顎骨や軟組織の存在のた めに正確なプレート形態が得られない場合があること, 仮固定用プレートと本固定用プレートを併用する場合 にはネジ止めする場所がお互いに干渉する，などが欠 点となる.

区域切除前に, 顎外固定装置を用い下顎の顎位を記 録する術式 5,6$)$ は上記の欠点を解消しているが, 装 置の脱着に煩わしさがあった。

\section{2 ) 本術式について}

区域切除術後に残存顎を正確に復位させることは， 形態的にも, 顎関節や咀嚼筋の機能からも, 残存歯牙 の咬合機能の回復の上からも重要である.下顎再建に おいては, 残存する下顎骨を正確に復位させ, かつ固 定された状態下で再建術を施行することが望ましい. しかし, 顎骨の復位と再建顎の位置決定を, 短時間に 行うことは相当に困難であり，簡便な術式が望まれた.

本術式では顎外固定装置の材料として, 入手が容易 で滅菌済みの即時重合レジンである, 骨セメント (サー ジカル シンプレックス) を用いた。この製品は, フィ
ルターによりろ過滅菌されたモノマー $20 \mathrm{ml}$ と, ガン マー線照射で滅菌されたポリマー $40 \mathrm{~g}$ で成っている.

顎外固定装置の強度は, レジンが注入されるチュー ブの径によって大きく異なるので, 初期の症例では各 種の径のチューブを用い, 残存歯牙の咬合状態を観察 した. その結果, 屈曲部位でも内腔が狭窄しにくい柔 軟なチューブを選択すれば, オトガイ部を含む再建で あっても，8 $\mathrm{mm}$ 程度の径で正確に復位できることを 確認し, その後の症例では $8 \mathrm{~mm}$ の径を用いている.

今回, 報告した方法の利点としては, 以下が挙げら れる.

（1）顎位保持装置を受ける固定装置のネジを固定 した後に,チューブに注入したセメントを硬化させ， 同時に固定装置と一体化させ顎位保持装置を完成する ので, 再固定時のネジ止めの際に応力が加わりにくく, 残存下顎骨の復位が正確である.

(2) オトガイ部や下顎角部の再建では, 顎位保持 装置の形態と術中の印記によって, 形態の三次元的な 目安を得られる。

(3) 手術の進行に応じて, 顎位保持装置は簡単に 脱着できるので, 再建術の手術操作の障害とならない.

（4）所要時間は短く, 技術的にも容易で, 特殊な器 具を必要としない.

\section{結語}

下顎区域切除の再建の際に, 残存下顎骨を復位させ る簡便な位置決め法を考案したので報告した.

\section{引用文 献}

1）岡野博郎, 森田章介：下顎の悪性腫瘍の手術. 大谷隆俊, 園山 昇, 他 編 : 図説口腔外科 手術学 中巻, 1 版, 医歯薬出版, 東京, 1988, 501-516.

2）堀越達郎：下顎腫場の外科. 堀越達郎 編 : 図 説 䫟・顔面・ 口腔手術学, 1 版, 書林, 東京, 1976, 214-231.

3）長谷川 明, 渡部 至, 他: Titanium plate 補強による下顎骨即時再建術について. 日口外 誌 21: 44-51 1975 .

4) Saunders, J.R., Hirata, R.M., et al: Definitive mandibular replacement using reconstruction plates. Am J Surg 160: 3873891990.

5) Wessberg, G.A., Schaefer, S.D., et al: Monophasic extraskeletal mandibular fixation in head and neck surgery. Ann Otol Rhinoi Laryngol 91: 292-296 1982.

6) Buchbinder, D., Urken, M.L., et al: Bone contouring and fixation in functional primary microvascular mandibular reconstruction. Head Neck Surg 13: 191-199 1991. 